J. Appl. Glycosci., 53, 187-192 (2006)

(C) 2006 The Japanese Society of Applied Glycoscience

Regular Paper

\title{
$\alpha$-Amylase Affects Starch Accumulation in Rice Grains
}

(Received March 9, 2006; Accepted April 21, 2006)

\author{
Satoru Asatsuma, ${ }^{1, *}$ Chihoko Sawada, ${ }^{1, *}$ Aya Kitajima, ${ }^{1}$ Tsuyoshi Asakura ${ }^{1}$ and Toshiaki Mitsui ${ }^{1,2, * *}$ \\ ${ }^{1}$ Laboratories of Plant and Microbial Genome Control, Graduate School of Science and Technology and \\ ${ }^{2}$ Department of Applied Biological Chemistry, Niigata University (8050, Ikarashi-2, Niigata 950-2181, Japan)
}

\begin{abstract}
Amylase isoforms I-1 and II-4 were found in rice grains during ripening, $\alpha$-amylase II-4 being the most predominant isoform. To determine their functions in ripening seeds, we generated a series of transgenic rice plants transformed with $\alpha$-amylase I-1 and $\alpha$-amylase II-4 cDNA under the control of Cauliflower mosaic virus 35S promoter. These isoforms were increased in young shoot and mature leaf tissues of the transgenic plants at both mRNA and protein levels. The starch accumulation in leaves was reduced to $42-82 \%$ of that in the wild-type. The transgenic lines A3-1 and D1-4, which overexpressed $\alpha$-amylase I-1 and $\alpha$-amylase II-4, respectively, were examined further. The enzyme activity was increased in both seeds, and the increase was greater in D1-4. The dry weight of A3-1 and D1-4 seeds was decreased approximately 4 and 11\%, respectively. White immature grains frequently appeared in both lines, with severer abnormalities seen in D1-4. These results strongly suggest that the increase of $\alpha$-amylase activities inhibits the accumulation of reserve starch and lowers the grain quality of rice.
\end{abstract}

Key words: $\alpha$-amylase, Oryza sativa L., ripening seeds, starch, transgenic plant

$\alpha$-Amylases (EC 3.2.1.1) in cereal are polymorphic enzymes. Ten distinct $\alpha$-amylase genes have been cloned and sequenced, ${ }^{1-3)}$ and more than 20 native $\alpha$-amylase isoforms have been identified and characterized in rice. ${ }^{4-6)} \alpha$ Amylase I- 1 encoded by RAmylA is a glycoprotein bearing typical $\mathrm{N}$-linked oligosaccharide chains. ${ }^{7,8)}$ This isoform is heat-stable compared with the other isoforms. The conjugation of an oligosaccharide side chain to polypeptide was thought to be involved in its heat-stability. ${ }^{9,10)}$ In germinating rice seeds, the expression of $\alpha$-amylase I- 1 is regulated by gibberellin at both transcriptional and posttranscriptional steps. ${ }^{11,12)}$ The enzyme is synthesized in the scutellar epithelium and the aleurone layer, and subsequently secreted to the starchy endosperm. ${ }^{6}$ The experimental data obtained by employing the transgenic rice plant with suppressed expression of $\alpha$-amylase I-1 revealed that this isoform plays an important role during seed germination and seedling growth. ${ }^{13)} \alpha$-Amylase II-4 encoded by $R A m y 3 D$ (Amy3) is actively expressed in suspension-cultured cells derived from the rice embryo. The $\alpha$-amylase II- 4 expression is regulated by sugars transcriptionally and post-transcriptionally. ${ }^{14-18)}$ At an early stage of germination, $\alpha$-amylase II- 4 is a predominant isoform expressed in the coleoptile tissues of rice seed. This isoform is also expressed and secreted from the scutellar epithelium at the early stage of germination and the aleurone layer at the later stage. $\left.{ }^{6}\right)$ The expression of $\alpha$-amylase II-3 encoded by RAmy3E (Amy8) was detected in germinating seeds and suspension-cultured cells derived from the embryo in rice. ${ }^{3,519)}$ The transcription of the $\alpha$-amylase II-3 gene has been reported to be regulated by sugars and hormones through Myb transacting factors. ${ }^{20)} \alpha$-Amylase

\footnotetext{
${ }^{*}$ Contributed equally to this work.

${ }^{* *}$ Corresponding author (Tel./Fax. +81-25-262-6641, E-mail: t. mitsui@agr.niigata-u.ac.jp).
}

II-5/6 encoded by $R A m y 3 B / C$ was also detected in the germinating seeds. ${ }^{5}$ Similar to the other $\alpha$-amylase isoforms, the expression of $\alpha$-amylase II-5/6 was suggested be regulated by gibberellin and abscisic acid in germinating seeds. ${ }^{5}$

As described above, $\alpha$-amylase is a key enzyme for germination and seedling growth of rice seeds. However, we found the typical $\alpha$-amylase isoforms I- 1 and II- 4 in ripening seeds. We examined the function of $\alpha$-amylase in grain during the ripening period in transgenic rice plants overexpressing the enzyme isoforms.

\section{MATERIALS AND METHODS}

Plant materials. The rice variety (Oryza sativa L. cv. Nipponbare) used in this study was supplied from the Niigata Agricultural Research Institute (Niigata, Japan).

Assays. Starch and protein contents were determined as described by Matsukura et al.$^{21)}$ and Bradford, ${ }^{22}$ respectively. $\alpha$-Amylase activity was determined using $\beta$-limit dextrin as the substrate. $\beta$-limit dextrin was prepared by hydrolyzing potato starch solution $(2 \% \mathrm{w} / \mathrm{v}$ in $50 \mathrm{~mm}$ acetate buffer, $\mathrm{pH} 5.3$ ), using crystalline potato $\beta$-amylase free from $\alpha$-amylase $\left(24 \mathrm{~h}, 30^{\circ} \mathrm{C}\right)$. $0.3 \% \beta$-limit dextrin dissolved in $50 \mathrm{mM}$ acetate buffer ( $\mathrm{pH}$ 5.3) containing 1 $\mathrm{mM} \mathrm{CaCl} \mathrm{Cl}_{2}$ served as the substrate. The reaction mixture containing $0.2 \mathrm{~mL}$ each of substrate and enzyme solution was incubated at $37^{\circ} \mathrm{C}$ for $5 \mathrm{~min}$; the reaction was stopped by adding $0.5 \mathrm{~mL}$ of $\mathrm{I}_{2}$-KI solution, followed by measurement of the decrease in Absorbance at $620 \mathrm{~nm}$ upon addition of $2 \mathrm{~mL} \mathrm{H}_{2} \mathrm{O}$. One enzyme unit was defined as the enzyme activity causing $10 \%$ absorbance decrease at 620 nm under the stated assay conditions.

Binary vector constructions and plant transformations. pZH2B-35S-AmyI-1 was constructed for producing transgenic rice plants overexpressing $\alpha$-amylase $\mathrm{I}-1$ as de- 
scribed previously. ${ }^{13,23)}$ The $\alpha$-amylase II-4 gene including the terminator sequence was PCR-amplified using a plasmid pAmyII-4 containing the $1.6 \mathrm{~kb}$ full-length $\alpha$-amylase II-4 cDNA, which is essentially identical to pOS137 (accession number M24287) ${ }^{1)}$ except there is no HindIII site in the coding region, as the DNA template and BamHI-Nter ( $5^{\prime}$-atcgggatccatgaagaacaccagcagc-3') and EcoRI-C-ter $\left(5^{\prime}\right.$-atcggaattcaaaactcactgatcggtgca-3 $\left.{ }^{\prime}\right)$ flanking primers. The PCR product was digested by Bam HI and Eco RI and inserted into the corresponding restriction sites of Bam HIEcoRI digested pTN1-35S-AmyI-1 to create pTN1-35SAmyII-4 for producing rice plants overexpressing $\alpha$-amylase II-4. ${ }^{13)}$ These vectors were transformed into the competent cells of Agrobacterium tumefaciens strain EHA $101^{24)}$ treated with $20 \mathrm{~mm} \mathrm{CaCl}_{2}$. The methods of Agrobacterium-mediated transformation and regeneration of rice plants were as described by Hiei et al ${ }^{25)}$ and Asatsuma et al ${ }^{13)}$ The plants were eventually transferred to soil in pots and grown to maturity in a greenhouse.

Preparation of antibodies. The cDNA library from total RNA isolated from the scutellar tissues of germinating rice seeds at day- 6 was created with pBluescript II SK (+) according to the manufacturer's protocol (Takara). The cDNA library was screened with $\alpha$-amylase II-5 (RAmy3 $B$ )- and II-6 (RAmy3C)-specific probes. The complete cDNAs thus obtained, were designated as AmyII-5 and AmyII -6, and were identical to accession number X56337 and X56338, respectively. The coding regions of AmyII-5 and AmyII-6 were PCR-amplified using the plasmids pAmyII-5 and pAmyII-6 as DNA template and the XhoIN-ter (AmyII-5: 5'-tactcgagatggcaaagcgcatagcctc-3', AmyII6: 5'-tactcgagatggcaaagcattccaccac-3') and BamHI-C-ter (AmyII-5: 5'-atggatcctaatagtggtgccgcctg-3', AmyII-6: 5'atggatcctagtggcgecgcctgctg-3') flanking primers, and the XhoI and Bam HI digested PCR product was inserted into the XhoI/Bam HI sites of pET-15b (Novagen) to construct pET15b-His-AmyII-5 and pET15b-His-AmyII-6, respectively, and these plasmids were transformed into Escherichia coli BL21. His-tagged $\alpha$-amylase II-5 and II-6 were purified from isopropyl-1-thio- $\beta$-D-galactopyranosideinduced bacterial cultures and affinity-purified according to the manufacturer's instruction on NiNTA resin (Amersham). Antiserum was obtained from rabbits immunized with each purified protein, and used as anti- $\alpha$-amylase II5 and II-6 antibodies. The preparation and specificity of rabbit polyclonal anti- $\alpha$-amylase I-1, II-4, anti-UDPglucose pyrophosphorylase antibodies and mouse polyclonal anti- $\alpha$-amylase II-3 antibodies were as described previously. ${ }^{6,10)}$

Southern, Northern, and Western blot analyses. Genomic DNA $(5 \mu \mathrm{g})$ isolated from young leaves of control and transgenic rice plants was digested with EcoRI, and separated by gel electrophoresis on $1 \%$ agarose gels and blotted onto a Hybond- $\mathrm{N}^{+}$membrane (Amersham). The $\alpha$-amylase I-1- and $\alpha$-amylase II-4-gene-specific DNA $^{6,26)}$ were used as the radioactive probe for Southern blot analysis. Northern ${ }^{18,26)}$ and Western blotting ${ }^{6,10)}$ were performed according to the procedure described previously. When peroxidase-conjugated anti-rabbit (or mouse) IgG IgG was used as the second antibody, the protein bands were visualized with ECL (enhanced chemiluminescence, Amersham), and quantified by LAS 3000 (Fujifilm). $\left[{ }^{35} \mathrm{~S}\right]$-labeled anti-rabbit IgG IgG was also used as the second antibody, and autoradiography and quantification were carried out by BAS 5000 (Fuji-film). Each amount of $\alpha$-amylase I- 1 and II- 4 protein expressed in the wild-type plants was normalized to 1 unit.

\section{RESULTS AND DISCUSSION}

Western blot analysis revealed the expression of $\alpha$ amylase I-1 and II-4 in the developing seeds at 10 days after heading, whereas the other isoforms, II-3, II-5 and II-6, were hardly detectable. $\alpha$-Amylase II- 4 was the most predominant isoform in the rice grains (Fig. 1).

Southern hybridization revealed the presence of transgenes of AmyI-1 and AmyII-4 in the regenerated transgenic rice plants produced by Agrobacterium-mediated transformation with pZH2B-35S-AmyI-1 and pTN1-35SAmyII-4 under the control of Cauliflower mosaic virus $35 \mathrm{~S}$ promoter, respectively. The obtained transgenic rice plants, 9 lines for pZH2B-35S-AmyI-1 and 21 lines for pTN1-35S-AmyII-4, had 1 to 8 copies of the transgene (data not shown). The expression of $\alpha$-amylase genes at mRNA and protein levels in these transgenic lines was examined by Northern and Western blot analyses, respectively. As shown in Fig. 2, both transgenic lines exhibited a marked increase of each $\alpha$-amylase expression in young shoot and mature leaf tissues in the $\mathrm{T}_{1}$ generation. We selected A3-1 and D1-4 lines to further characterize the

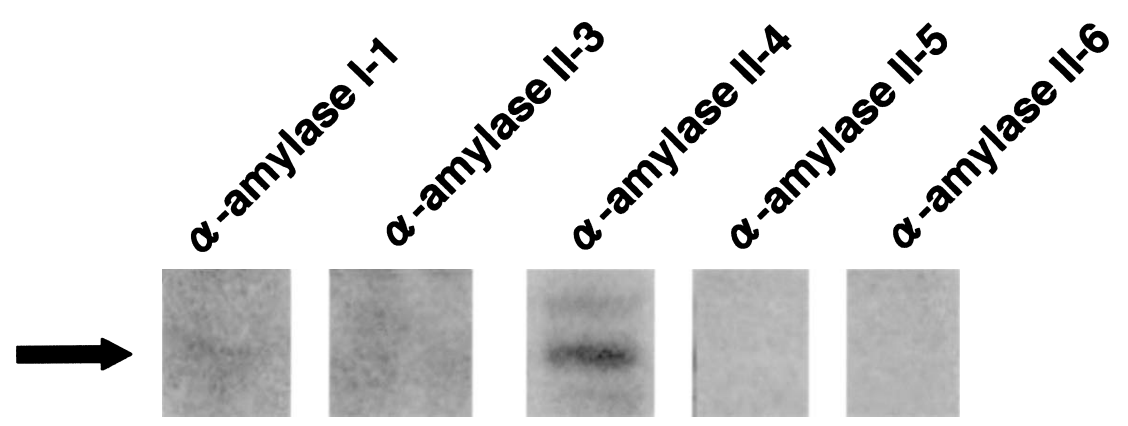

Fig. 1. $\alpha$-Amylase isoforms expressed in rice ripening seeds.

An aliquot of the protein sample extracted from 10 seeds (10 days after heading) was subjected to Western blotting with either anti- $\alpha$-amylase I-1, II-3, II-4, II-5 or II-6 antiserum. Peroxidase-conjugated second antibodies were used to visualize the $\alpha$-amylase bands. The arrow represents the $\alpha$-amylase bands. 
B

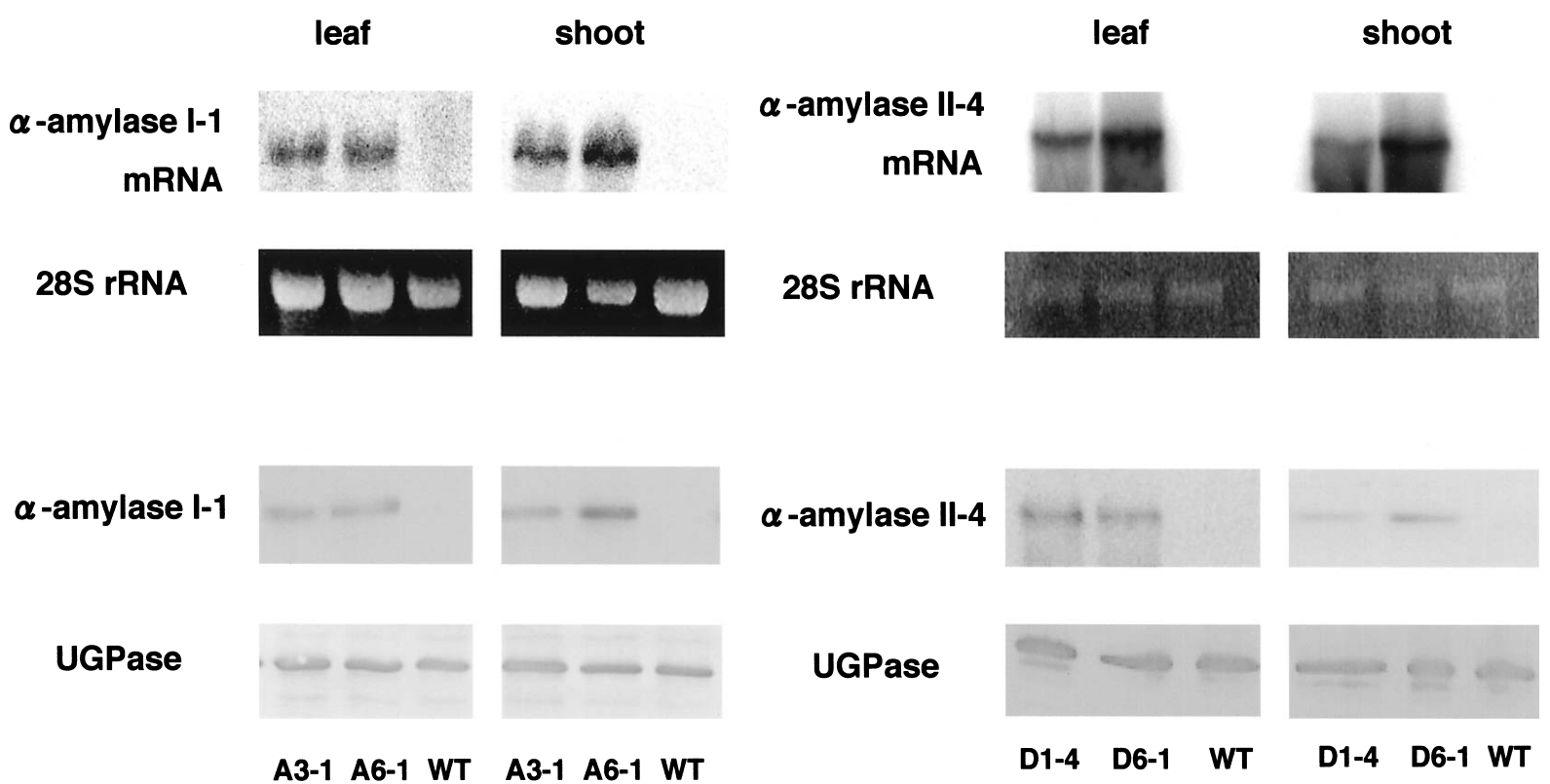

Fig. 2. Characterization of the leaves overexpressing $\alpha$-amylase I-1 (A) and II-4 (B).

Northern and Western blot analyses of $\alpha$-amylase I-1 and II-4 expression were performed in shoot and leaf tissues from a series of transgenic and wild-type plants. An aliquot of RNA isolated from mature leaves (2-month) and shoot tissues (5-day) was subjected to Northern blotting with either [ $\left.{ }^{32} \mathrm{P}\right]$-labeled $\alpha$-amylase I-1 or II-4 gene-specific probe (upper panel). The protein extracts were subjected to Western blotting with either anti- $\alpha$-amylase I-1 or II-4 and anti-UGPase antisera (lower panel). Peroxidase-conjugated anti-rabbit IgG IgG was used as the second antibody. A and D series represent the transgenic lines overexpressing $\alpha$-amylase I- 1 and II- 4 , respectively. WT represents the wild type.

phenotypes of transgenic plants, since both lines exhibited stable growth and seed formation.

In both $\alpha$-amylase I- 1 and II- 4 overexpression lines, A31 and D1-4, amylase activities were markedly increased in leaves of transgenic plants, and the activity in A3-1 was about 1.4 fold higher than that in D1-4 (Fig. 3B), though the overexpression of $\alpha$-amylase isoform did not influence the expression of other isoforms (Fig. 3C). Starch contents were significantly decreased in the leaves of A3-1 and calculated to be approximately $42 \%$ of those of the wildtype (Fig. 3A). While, the starch contents in the leaves of D1-4 were slightly reduced, which was $82 \%$ of that of the wild-type (Fig. 3A).

Our previous investigation ${ }^{13)}$ revealed that the hydrolytic breakdown of reserve starch by $\alpha$-amylase I- 1 plays a significant role in the stimulation of seed germination processes, including seedling growth. However, after transplanting to pots, plants overexpressing both $\alpha$-amylase I-1 and $\alpha$-amylase II- 4 were indistinguishable from those of the wild-type in growth and morphology (data not shown). The results presented in this study showed that the partial disturbance of starch accumulation in leaves caused by the $\alpha$-amylase overexpression (Figs. 2 and 3) does not affect the plant growth of rice.

The $\alpha$-amylase activities were markedly higher in ripening seeds of the $T_{3}$ generation of A3-1 and D1-4 than in the wild-type (Fig. 4A). In particular, the level of $\alpha$ amylase activity was much higher in the D1-4 line overexpressing $\alpha$-amylase II- 4 than in the A3-1 line during an early stage of ripening (Fig. 4A). Furthermore, the tissue growth of ripening seeds of transgenic lines was significantly delayed in comparison with the wild type
(Fig. 4B).

We further analyzed the phenotypic characteristics of mature seeds of the A3-1 and D1-4 lines. Quantification of $\alpha$-amylase expression by western blot analyses showed that the amount of $\alpha$-amylase I- 1 proteins in the mature seeds of the A3-1 line increased to 36 fold, while $\alpha$ amylase II-4 in the D1-4 line increased to 44 fold against the basal level in the wild-type (Fig. 5A). The enzyme activities were induced in seeds of both A3-1 and D1-4, and the inducing activity was much higher in D1-4 (Fig. 5B). The dry weight of mature seeds of A3-1 and D1-4 was reduced $4 \%$ in $\mathrm{A} 3-1$ and $11 \%$ in D1-4 compared to that of the wild-type (Fig. 5C). The seed weight of rice closely correlated with the starch contents (data not shown); therefore, we considered that the reduction of seed weight resulted from the decrease of reserve starch. The quality of seeds of A3-1 and D1-4 was evaluated by reflection and transmission views (Fig. 6). As shown in Table 1, the percentages of normal good grains was calculated to be 90, 54 and 36\%, in the wild-type, A3-1 and D1-4, respectively. Dominant morphological phenotypes of abnormal seeds of A3-1 and D1-4 were white core and whole opaque white, respectively (Fig. 6 and Table 1). Collectively, these results strongly suggested that overexpression of $\alpha$-amylase activity inhibited the accumulation of reserve starch and lowered the grain quality of rice.

A starch-excess phenotype (sex4) of Arabidopsis reportedly exhibited a reduction in chloroplastic $\alpha$-amylase activity and a reduced rate of starch breakdown in leaves at night, ${ }^{27)}$ which shows a deficiency in AtAMY3, plastidial $\alpha$-amylase protein. However, T-DNA knockout mutants of AtAMY3 have been reported to show the same di- 
A
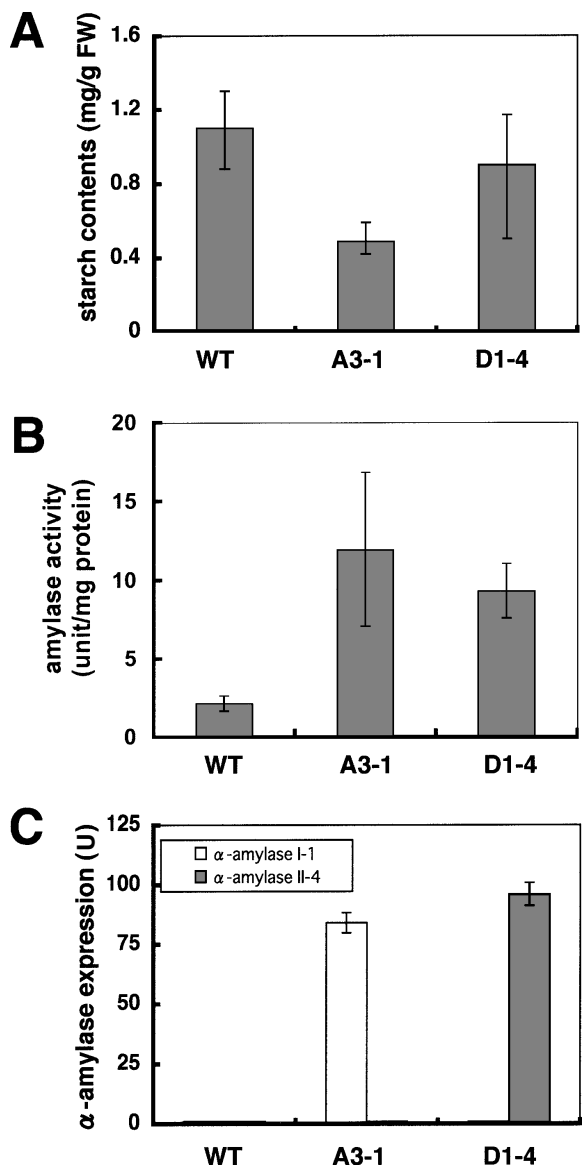

Fig. 3. Starch contents of the leaves overexpressing $\alpha$-amylase I-1 (A3-1) and $\alpha$-amylase II-4 (D1-4).

(A) Starch contents in the leaves (2-month) of A3-1 and D1-4. Leaves at the same developmental stage and of the same size were carefully harvested immediately after sunset, and tested to determine the starch contents in leaves. Each value is the mean \pm SD of triplicate experiments. (B) Amylase activities in leaves from transgenic (A3-1 and D4-1) and wild-type plants. Each value is the mean \pm SD of triplicate experiments. (C) Quantitation of expression of $\alpha$-amylase I- 1 and $\alpha$-amylase II- 4 proteins in the leaves by immunoblotting with $\left[{ }^{35} \mathrm{~S}\right]$-labeled second antibodies. Each amount of $\alpha$-amylase I- 1 and II-4 in the wild type was normalized to $1 \mathrm{U}$ as described in MATERIALS AND Methods. The data represent the average of triplicate experiments.

urnal pattern of transitory starch metabolism as the wildtype plants, showing that AtAMY3 is not required for transitory starch breakdown. ${ }^{28}$ Knockout mutants of the other $\alpha$-amylase-like proteins (AtAMY1 and AtAMY2), which are extra-plastidial amylases, also displayed normal starch breakdown in the dark. ${ }^{28}$ Therefore, it was concluded that $\alpha$-amylase is not necessary for transitory starch breakdown in Arabidopsis leaves. However, the results presented in Figs. 3 and 5 revealed that $\alpha$-amylase is involved in the starch accumulation (degradation) in both source and sink tissues of rice.

Rice $\alpha$-amylase I- 1 and $\alpha$-amylase II- 4 are well-known secretory enzymes in the germinating seeds. ${ }^{4)}$ By expression and targeting of $\alpha$-amylase I-1 fused to green fluorescent protein, $\alpha$-amylase I-1 molecules have been found to occur in chloroplasts and amyloplasts in living leaf cells of rice plants. ${ }^{13)}$ By immunocytochemical studies with anti- $\alpha$-amylase antibodies, Chen et al ${ }^{29)}$ showed that in suspension-cultured rice cells, some $\alpha$-amylases are lo-
A
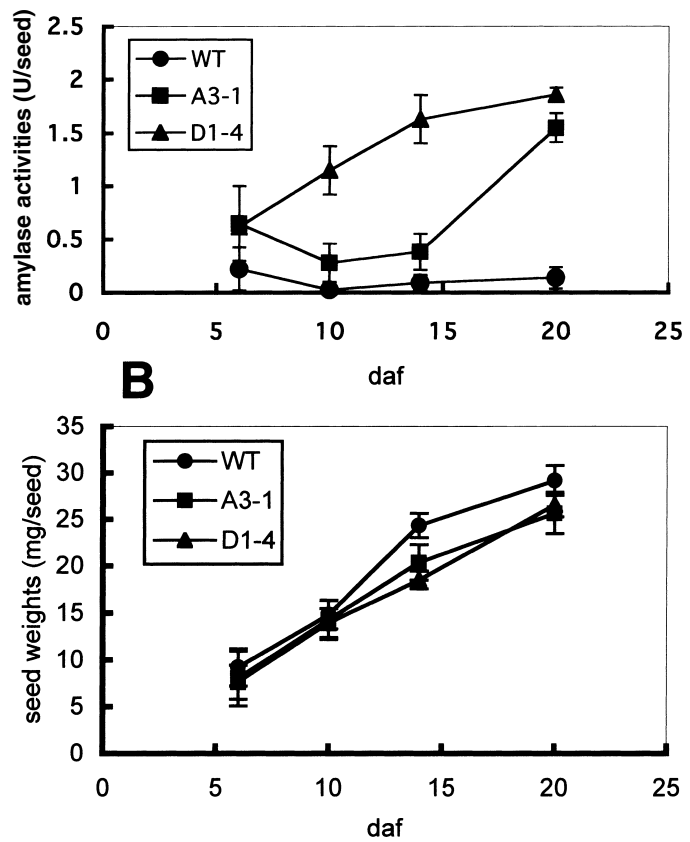

Fig. 4. Changes in amylase activities (A) and seed weights (B) in ripening seeds from the transgenic (A3-1 and D1-4) and wild-type plants.

An aliquot of the extracts from 10 seeds at indicated daf (days after heading) was subjected to the enzyme assay. The data represent the average of triplicate experiments.

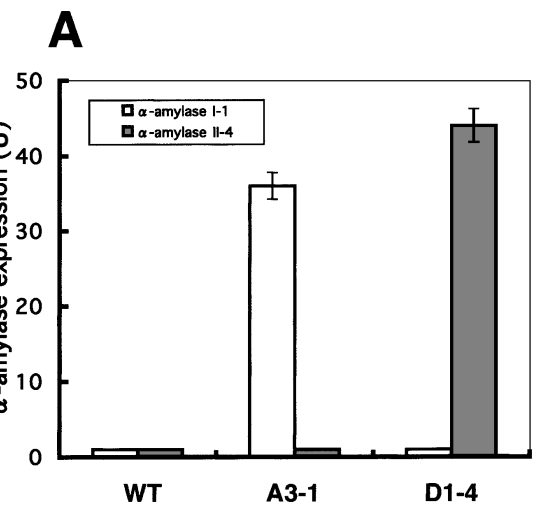

B

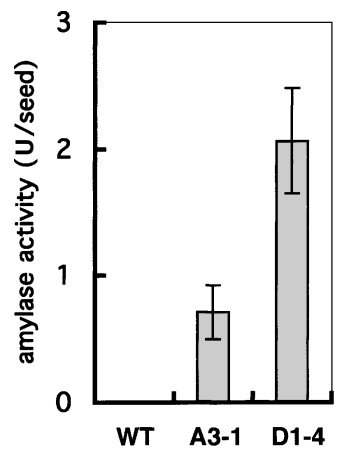

C

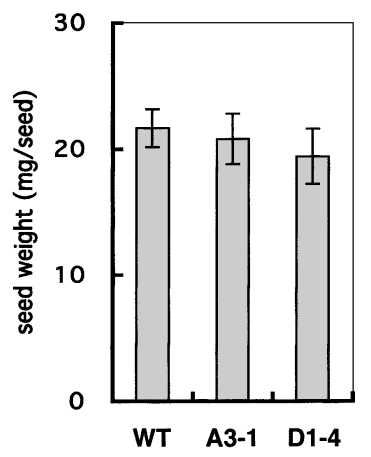

Fig. 5. Characteristics of mature grain overexpressing $\alpha$-amylase I-1 (A3-1) and II-4 (D1-4).

The proteins extracted from 10 seeds of hulled rice were subjected to Western blotting with either anti- $\alpha$-amylase I- 1 or II- 4 antiserum (A) and $\alpha$-amylase assay (B). (C) Weight of 50 grains randomly selected in each line was measured. In immunodetection, each amount of $\alpha$-amylase I- 1 and II- 4 in the wild type was normalized to $1 \mathrm{U}$ as described in MATERIALS AND METHODS. Each value is the mean \pm SD of triplicate experiments. 

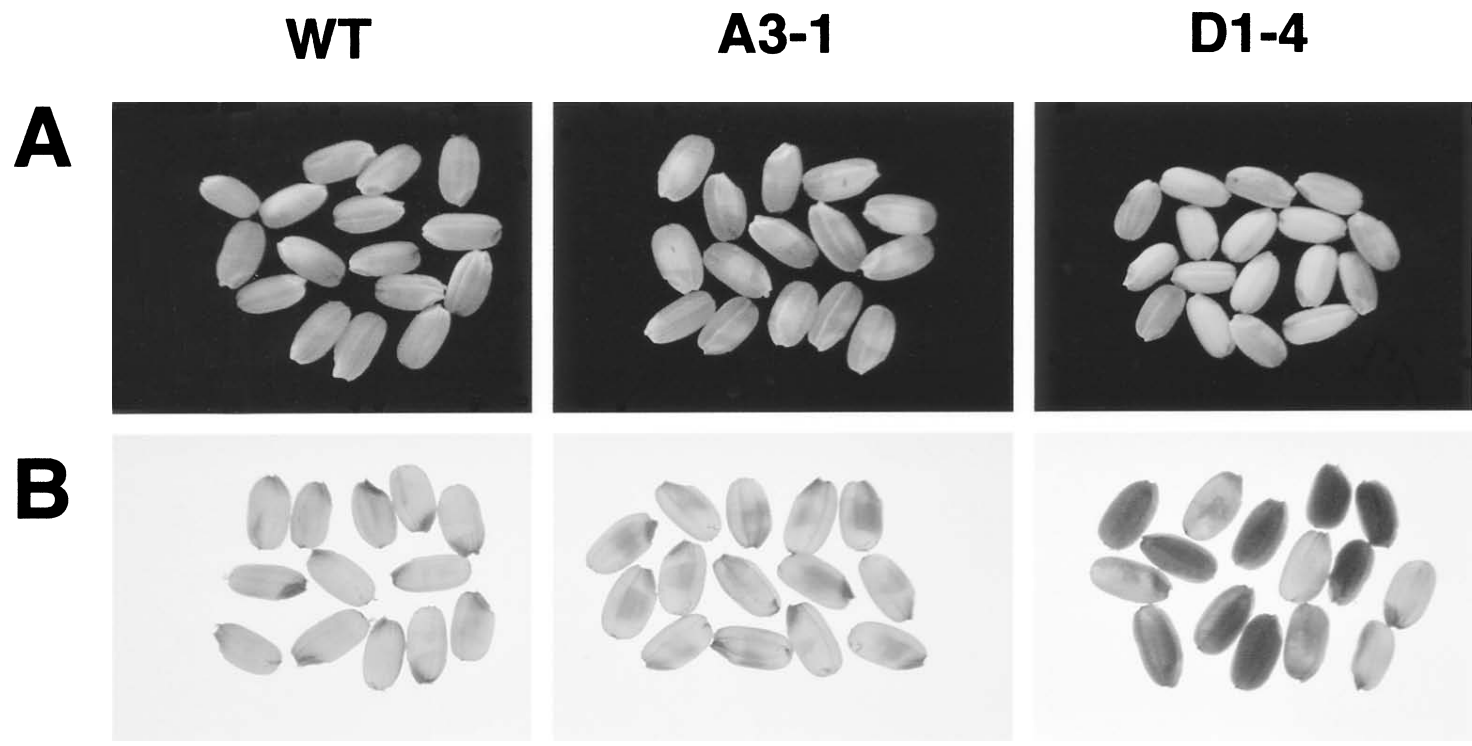

Fig. 6. Grain quality of the transgenic rice overexpressing $\alpha$-amylase I-1 (A3-1) and II-4 (D1-4).

(A) Reflection view; (B) transmission view.

Table 1. Morphological characteristics of seeds harvested from transgenic rice plants overexpressing $\alpha$-amylase I-1 (A31) and II-4 (D1-4).

\begin{tabular}{lccc}
\hline & Normal & White core & $\begin{array}{c}\text { Whole opaque } \\
\text { white }\end{array}$ \\
\hline WT & $90 \%$ & $10 \%$ & $0 \%$ \\
A3-1 & $54 \%$ & $46 \%$ & $0 \%$ \\
D1-4 & $36 \%$ & $34 \%$ & $3 \%$ \\
\hline
\end{tabular}

Fifty grains randomly selected in each line were hulled and evaluated.

calized in starch granules within amyloplasts. Quite recently, rice $\alpha$-amylase encoded by $\alpha A m y 3$ (RAmy $3 D$ ) was shown to be localized simultaneously in both plastids and extracellular compartments of tobacco leaves and suspension-cultured cells. ${ }^{30)}$ Judging from their loss-of-function and gain-of-function studies, they considered that the signal peptide of $\alpha A m y 3$ is sufficient for targeting $\alpha A m y 3$ to plastids and extracellular compartments via the ER in transgenic tobacco and rice cells. Moreover, Villarejo et $a l .^{31)}$ reported evidence for a protein transported through the secretory pathway en route to the chloroplast in Arabidopsis cells. All these experimental results strongly suggested that $\alpha$-amylase I-1 and II-4 must be localized in the amyloplasts through uncharacterized protein traffic from the secretory pathway and function as a regulator for starch accumulation in ripening rice seeds. However, further investigation will be necessary to understand in detail the mechanism of protein traffic from the secretory pathway to the plastids in the endosperm of ripening seeds.

What is the physiological meaning of $\alpha$-amylase expression in rice seeds during ripening? Recently, we found a significant increase of $\alpha$-amylase activity in rice seeds exposed to abnormally high temperatures during the ripening period. Heat stress during the ripening period was shown to cause white immature grains, which is similar to the morphological characteristics of grains overexpressing $\alpha$-amylases (Mitsui et al., unpublished data). Thus, we consider the possibility that rice plants may express $\alpha$-amylases to utilize the reserve starch as sources of osmotic regulation and energy for adapting to abiotic stress, such as high temperatures and drought.

This research was supported by Grants-in-Aid No. 16658042 and 17051011 from the Ministry of Education, Culture, Sports, Science and Technology, and a Grant for Promotion of Niigata University Research Projects (Japan). We wish to thank Drs. M. Ohshima, M. Kuroda and M. Kawada (Hokuriku Research Center, National Agricultural Research Center, Japan) for providing pTN1 and pZH2B plasmids.

\section{REFERENCES}

1 ) N. Huang, G.L. Stebbins and R.L. Rodriguez: Classification and evolution of $\alpha$-amylase genes in plants [Erratum appears in Proc. Natl. Acad. Sci. USA, 89, 12209 (1992)]. Proc. Natl. Acad. Sci. USA, 89, 7526-7530 (1992).

2 ) J.K. Kim and R. Wu: Nucleotide sequence of a high-pI rice (Oryza sativa) amylase gene. Plant Mol. Biol., 18, 399-402 (1992).

3 ) S.M. Yu, Y.C. Lee, S.C. Fang, M.T. Chan, S.F. Hwa and L.F. Liu: Sugars act as signal molecules and osmotica to regulate the expression of alpha-amylase genes and metabolic activities in germinating cereal grains. Plant Mol. Biol., 30, 1277-1289 (1996).

4 ) T. Mitsui and K. Itoh: The $\alpha$-amylase multigene family. Trends Plant Sci., 2: 255-261 (1997).

5 ) Y. Nanjo, S. Asatsuma, K. Itoh, H. Hori and T. Mitsui: Proteomic identification of $\alpha$-amylase isoforms encoded by RAmy $3 B / 3 C$ from germinating rice seeds. Biosci. Biotechnol. Biochem., 68: 112-118 (2004).

6 ) Y. Nanjo, S. Asatsuma, K. Itoh, H. Hori, T. Mitsui and Y. Fujisawa: Posttranscriptional regulation of $\alpha$-amylase II-4 expression by gibberellin in germinating rice seeds. Plant Physiol. Biochem., 42: 477-484 (2004).

7 ) D. Lecommandeur, Y. Sirou and C. Laurière: Glycan research on barley, maize, oats, and sorghum grain $\alpha$-amylases: comparison with rice $\alpha$-amylase. Arch. Biochem. Biophys., 278, 245-250 (1990).

8 ) M. Hayashi, A. Turu, T. Mitsui, N. Takahashi, H. Hanzawa, Y. Arata and T. Akazawa: Structure and biosynthesis of the xylose-containing carbohydrate moiety of rice $\alpha$-amylase. Eur. J. Biochem., 191, 287-295 (1990).

9 ) M. Terashima, A. Kubo, M. Suzawa, Y. Itoh and S. Katoh: The roles of the N-linked carbohydrate chain of rice $\alpha$-amylase in thermostability and enzyme kinetics. Eur. J. Biochem., 226, 
249-254 (1994).

10) T. Mitsui, J. Yamaguchi and T. Akazawa: Physicochemical and serological characterization of rice $\alpha$-amylase isoforms and identification of their corresponding genes. Plant Physiol., 110, 1395-1404 (1996).

11) K. Itoh, J. Yamaguchi, N. Huang, R.L. Rodriguez, T. Akazawa and K. Shimamoto: Developmental and hormonal regulation of rice $\alpha$-amylase (RAmylA)-gusA fusion genes in transgenic rice seeds. Plant Physiol., 107, 25-31 (1995).

12) M.A. Kashem, H. Hori, K. Itoh, T. Hayakawa, Y. Todoroki, N. Hirai, H. Ohigashi and T. Mitsui: Effects of $(+)-8^{\prime}, 8^{\prime}, 8^{\prime}-$ trifluoroabscisic acid on $\alpha$-amylase expression and sugar accumulation in rice cells. Planta, 205, 319-326 (1998).

13) S. Asatsuma, C. Sawada, K. Itoh, M. Okito, A. Kitajima and T. Mitsui: Involvement of $\alpha$-amylase I-1 in starch degradation in rice chloroplasts. Plant Cell Physiol., 46, 858-869 (2005).

14) E.E Karrer and R.L. Rodriguez: Metabolic regulation of rice $\alpha$ amylase and sucrose synthase genes in planta. Plant J., 2, 517-523 (1992).

15) M.T. Chan and S.M. Yu: The $3^{\prime}$ untranslated region of a rice $\alpha$-amylase gene functions as a sugar-dependent mRNA stability determinant. Proc. Natl. Acad. Sci. USA, 95, 6543-6547 (1998).

16) Y.S. Hwang, E.E. Karrer, B.R. Thomas, L. Chen and R.L. Rodriguez: Three cis-elements required for rice $\alpha$-amylase Amy $3 D$ expression during sugar starvation. Plant. Mol. Biol., 36, 331-341 (1998).

17) K. Toyofuku, T. Umemura and J. Yamaguchi: Promoter elements required for sugar-repression of the $R A m y 3 D$ gene for $\alpha$-amylase in rice. FEBS Lett., 428, 275-280 (1998).

18) T. Mitsui, T. Loboda, I. Kamimura, H. Hori, K. Itoh and S. Mitsunaga: Sucrose-controlled transport and turnover of $\alpha$ amylase in rice (Oryza sativa L.) cells. Plant Cell Physiol., 40, 773-783 (1999).

19) S.M. Yu, Y.H. Kuo, G. Sheu, Y.J. Sheu and L.F. Liu: Metabolic derepression of $\alpha$-amylase gene expression in suspensioncultured cells of rice. J. Biol. Chem., 266, 21131-21137 (1991).

20) C.A. Lu, T.H. Ho, S.L. Ho and S.M. Yu: Three novel MYB proteins with one DNA binding repeat mediate sugar and hormone regulation of $\alpha$-amylase gene expression. Plant Cell, 14, 1963-1980 (2002).

21) C. Matsukura, T. Saitoh, T. Hirose, R. Ohsugi, P. Perata and J. Yamaguchi: Sugar uptake and transport in rice embryo. Expression of companion cell-specific sucrose transporter (OSSUT 1) induced by sugar and light. Plant Physiol., 124, 85-93 (2000).

22) M.M. Bradford: A rapid and sensitive method for the quantitation of microgram quantities of protein utilizing the principle of protein-dye binding. Anal. Biochem., 72, 248-254 (1976).

23) P. Hajdukiewicz, Z. Svab and P. Maliga: The small, versatile pPZP family of Agrobacterium binary vectors for plant transformation. Plant Mol. Biol., 25, 989-994 (1994).

24) E.E. Hood, G.L. Helmer, R.T. Fraley and M.D. Chilton: The hyper-virulence of Agrobacterium tumefaciens A281 is encoded in a region of pTiBo542 outside of T-DNA. J. Bacteriol., 168: 1291-1301 (1986).

25) Y. Hiei, S. Ohta, T. Komari and T. Kumashiro: Efficient transformation of rice (Oryza sativa L.) mediated by Agrobacterium and sequence analysis of the boundaries of the T-DNA. Plant J., 6, 271-282 (1994).

26) M.A. Kashem, K. Itoh, S. Iwabuchi, H. Hori and T. Mitsui: Possible involvement of phosphoinositide- $\mathrm{Ca}^{2+}$ signaling in the regulation of $\alpha$-amylase expression and germination of rice seed (Oryza sativa L.). Plant Cell Physiol., 41, 399-407 (2000).

27) S.C. Zeeman, F. Northrop, A.M. Smith and T. Rees: A starchaccumulating mutant of Arabidopsis thaliana deficient in a chloroplastic starch-hydrolysing enzyme. Plant J., 15, 357-365 (1998).

28) T.S. Yu, S.C. Zeeman, D. Thorneycroft, D.C. Fulton, H. Dunstan, W.L. Lue, B. Hegemann, S.Y. Tung, T. Umemoto, A. Chapple, D.L. Tsai, S.M. Wang, A.M. Smith, J. Chen and S. M. Smith: $\alpha$-Amylase is not required for breakdown of transitory starch in Arabidopsis leaves. J. Biol. Chem., 280, 97739779 (2005).

29) M.H. Chen, L.F. Liu, Y.R. Chen, H.K. Wu and S.M. Yu: Expression of $\alpha$-amylases, carbohydrate metabolism, and autophagy in cultured rice cells is coordinately regulated by sugar nutrient. Plant J., 6, 625-636 (1994).

30) M.H. Chen, L.F. Huang, H.M. Li, Y.R. Chen and S.M. Yu: Signal peptide-dependent targeting of a rice $\alpha$-amylase and cargo proteins to plastids and extracellular compartments of plant cells. Plant Physiol., 135, 1367-1377 (2004).

31) A. Villarejo, S. Buren, S. Larsson, A. Dejardin, M. Monne, C. Rudhe, J. Karlsson, S. Jansson, P. Lerouge, N. Rolland, G.V. Heijne, M. Grebe, L. Bako and G. Samuelsson: Evidence for a protein transported through the secretory pathway en route to the higher plant chloroplast. Nat. Cell Biol., 7, 1224-1231 (2005).

\section{$\alpha$-アミラーゼはイネ穀粒における デンプン蓄積に影響を及ぼす \\ 浅妻 悟 ${ }^{1}$, 澤田千穂子 ${ }^{1}$, 北嶋 彩 ${ }^{1}$ \\ 朝倉 剛 ${ }^{1}$, 三ツ井敏明 ${ }^{1,2}$ \\ ${ }^{1}$ 新潟大学大学院自然科学研究科 \\ 植物・微生物ゲノムコントロール \\ (950-2181 新潟市五十嵐 2 の町 8050) \\ 2 新潟大学農学部応用生物化学 \\ (950-2181 新潟市五十嵐 2 の町 8050)}

イネの登熟期における種子において $\alpha$-アミラーゼアイ ソフォームである I-1 および II-4 の存在を確認した。それ らの登熟期における機能を調べるため，われわれは $\alpha$-ア ミラーゼI-1 および II-4 の cDNA にカリフラワーモザイク ウィルスの $35 \mathrm{~S}$ プロモーターをつなげたものを形質転換 した組換え体イネ系統を作出した。どちらのアイソ フォームも形質転換体植物の幼芽および緑葉組織におい て $\alpha$-アミラーゼの mRNA およびタンパク質の双方が増加 していた。葉におけるデンプン蓄積は, 野生系統と比べ てそれぞれ 42\%，82\% 減少していた， $\alpha$-アミラーゼ I-1 と

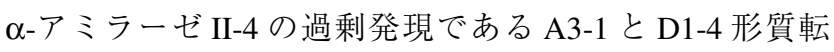
換体イネ系統をさらにそれぞれ調べたところ，両方の完 熟種子において高い酵素活性を示し, D1-4 においてはそ の増加が顕著であった. A3-1 と D1-4 の完熟種子の乾燥 重量にも有意な減少がみられ，それぞれ約 $4 \%, 11 \%$ の減 少であった。両系統で乳白米が多くみられ，D1-4におい

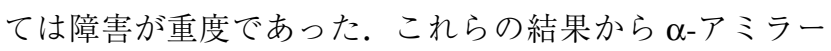
ゼ活性の増加は, 貯蔵デンプンの蓄積を抑制し, イネの 粒質を低下させることを強く示唆している. 